taken place in the past twelve months or more in accordance with the refinery expansion programme in Great Britain. Production of aviation and motor spirit was 2,923,181 tons as against $1,477,955$ tons in 1950 ; again, nearly half the output of refinery products was fuel oil-7,649,982 tons during 1951 and $3,805,198$ tons during 1950 . The refineries are processing almost entirely Middle East crude oil, thus saving dollar currency, and, in any event, the increased output represents a substantial saving in cost of the finished products.

\section{Archæology in Greece and Cyprus during the Year 1950-51}

THE survey, "Archæology in Greece, 1950-51", by J. M. Cook, to which is appended "Archæology in Cyprus, 1951", by A. H. S. Megaw, is published both in the annual report for the session 1950-51 of the British School of Archæology at Athens (pp. 60; from 9-13 George Street, London, W.1; 1952) and in Journal of Hellenic Studies, 52 (1952). The Second World War and its consequences have had one good effect in classical archæology, namely, that there has been less excavation and more study of what had already been excavated. Hence these two surveys, which are limited to field-work and finds of objects, are less sensational than sometimes in the past. The energetic Orlandos is repairing and restoring ancient and medieval buildings in many parts of Greece. The Americans continue their model exploration of the Agora (or public centre) of ancient Athens, the greatest and most solidly productive undertaking of classical archæology; it now seems that there is below the Agora a large cemetery of the Late Bronze Age. Of other excavations the most useful is that of Old Smyrna, where the Turks and British have found remains going back to the Early Iron Age ; this is important for the date and nature of the Greek colonization of the coast of Asia Minor. Elsewhere, expeditions have produced finds interesting in themselves, but of less general relevance. There is still a tendency to excavate without good reasons; perhaps, in this respect, rising costs will prove a blessing.

\section{Colonial Service : Recent Appointments}

THE following appointments have recently been made in the Colonial Service: P. Adames (agricultural officer, Sierra Leone), principal agricultural officer, Sierra Leone; E. G. Giglioli (assistant agricultural superintendent, British Guiana), agricultural superintendent, British Guiane; 'T. S. Jones (agricultural officer, Sierra Leone), senior agricultural officer, Sierra Leone ; C. H. B. Williams (deputy director of agriculture (crop husbandry), 'Trinidad), director of agriculture, Trinidad; A. Cawley (deputy director, (ieological Survey, Nigeria), director, Geological Survey, Uganda; C. E. W. Hoar (pathologist, Nigeria), pathologist, Uganda; R. E. Alvares (assistant pathologist, Hong Kong), pathologist, Hong Kong; J. P. Henderson (meteorologist, East African High Commission), assistant director, East African Meteorological Department; P. I. R. MacLaren (fisheries officer, Nigeria), fisheries officer, Game and Tsetse Fly Department, Northern Phodesia; Ong Chin Ghee (senior agriculture assistant, Sarawak), senior assistant agricultural officer, Sarawak ; D. W. A. Peters (laboratory technician, Medical Department, Somaliland Protectorate), laboratory superintendent, Virus Research Institute. Nigeria; A. McCallum, agricultural officer, Tangan- yika; A. J. Ouseley-Smith, agricultural officer, Uganda; Dr. H. J. F. Cairns, medical research officer, grade 3, Virus Research Institute, Uganda; P. J. Byrne, veterinary officer, Tanganyika; R. F. Apps, scientific officer, Royal Observatory, Hong Kong; J. A. C. Davies, agricultural officer, Sierra Leone; H. S. Deans, assistant conservator of forests, Jamaica; R. Good, educational psychologist, Northern Rhodesia; J. G. Halcrow, entomologist. Colonial Insecticides Research Unit, Mauritius ; R. C. Jones, hydrologist, Public Works Department, Kenya; R. M. Mabon, laboratory assistant, Veterinary Department, Tanganyika; Hon. P. L. A. O'Brien, geologist, Northern Rhodesia; Miss J. M. Slow, scientific officer, Maize and Produce Organization, Kenya; Dr. L. A. Whelan, soil chemist, Agricultural Department, Kenya.

\section{The Behaviour of Bower-birds}

Dr. L. HarRISON MatThews writes: "The article on 'The Behaviour of Bower-birds' that appeared in Nature of July 19 , p. 110 , is based on a review by Prof. Evelyn Hutchinson, of Yale University, that appeared in the American Scientist (40, No. 1). The writer of the article in Nature does not make it clear that this is a review by Prof. Hutchinson of original work published by Dr. A. J. Marshall at various times in Nature and the Proceedings of the Zoological Society of London. Prof. Hutchinson gives due credit to the author of the papers which he reviews, but it should also be made clear to readers of Nature that the original work was done, not by Prof. Hutchinson, but by Dr. Marshall".

The writer of the article did mention that it was based on Prof. Hutchinson's review ; but we regret, that no reference was made to the original work by Dr. A. J. Marshall.

\section{Announcements}

DR. H. A. B. Simons has been appointed to the readership in physics tenable at the Royal Free Hospital School of Medicine, London, from October 1.

TнE United States Government and the Institute of International Education are offering grants or supplements to existing grants for graduate study in an American university during the year 1953-54. Applicants must be citizens of the United Kingdom or the British Colonies, less than thirty years old, and must possess a bachelor's degree or its equivalent. Application forms (to be completed by November 1) can be obtained from Mrs. D. R. Dalton, Universities Department, English-Speaking Union, 37 Charles Street, Berkeley Square, London, W.1. Applicants from the British Commonwealth, other than those in the above category, should apply to the respective United States embassy in their own country for information on similar grants.

Erratum.-Mr. W. D. Furneaux writes that in his communication to Nature of July 5, p. 37 , entitled "Some Speed, Error and Difficulty Relationships within a Problem-solving Situation", he has inadvertently omitted a $t$ from equations (1) and (2), which should therefore read as follows:

$$
\begin{aligned}
& P_{S}=\int_{0}^{t} \frac{1}{\sigma_{S} t \sqrt{2 \pi}} \exp -(\log t \quad m D+S)^{2} / 2 \sigma_{S}^{2} \mathrm{~d} t \\
& P_{C}=1-\int_{0}^{t} \frac{1}{\sigma_{C} t \sqrt{2 \pi}} \exp \left(\log t-C^{\prime}\right)^{2} 2 \sigma^{2}{ }^{2} \mathrm{~d} t
\end{aligned}
$$

